\begin{tabular}{lccr} 
A R C H I V E & O F & M E C H A N I C A L & E N G I N E E R I N G \\
\hline VOL. LX & 2013 & Number 4 \\
10.2478/meceng-2013-0029 \\
Key words: unsteady flows, constant volume combustion
\end{tabular}

DAMIAN ŁAPIŃSKI, JANUSZ PIECHNA*

\title{
IMPROVEMENTS IN THE TURBO-ENGINE BY REPLACEMENT OF CONVENTIONAL COMBUSTION CHAMBER BY A PULSE COMBUSTION CHAMBER
}

\begin{abstract}
This paper comprises description of the turbo engine and evaluation of its analytical model. The analytical model was created to establish a benchmark for further evaluation of a wave rotor combustor (at constant volume). The wave rotor combustor concept was presented and discussed. Advantages of combustion at constant volume were described as well as the basic turbo engine updates required to reflect pulse combustor application. The calculation results for analytical model of a basic engine, and that equipped with pulse combustor are included in this paper. The paper describes the required changes in the engine structure and construction and the estimated thermodynamic improvements. Axial-type pulse multi-chamber combustion unit increasing the pressure and temperature of gases requires a special additional turbine utilizing additional energy and forming the interface between the standard compressor-turbine unit. Performance calculations done for an existing GTD-350 engine showed that constant-volume combustion process is valuable.
\end{abstract}

\section{Introduction}

The majority of the gas turbines and gas generators utilize constantpressure combustion processes. This approach is well known and wildly used in turbo engine industry around the world. In the past, there were (a few) attempts, to design engines that conduct the combustion process at constant volume $[1,2,3,4]$. However, these attempts were not sufficiently successful to introduce the engines to a mass production. The progress of civilization and engineering gives an opportunity to evaluate once again constant-volume combustion processes. To prove the advantages of constant-volume combustion processes in the proposed design, we selected the existing engine as a

* Warsaw University of Technology; Department of Power and Aeronautical Engineering Warsaw, Poland; E-mail: jpie@meil.pw.edu.pl 
benchmark. Many engines were taken into account, but the GTD-350 helicopter engine was finally chosen as a benchmark. The advantage of GTD-350 engine, in comparison to a classic one, is its very specific design. Exposure of combustor chamber gives an opportunity for fairly easy replacement and potential update of turbine system. Turbo-engine GTD-350 has a specific construction with compact compressor-turbine unit and external combustion chamber. We decided to replace it by the pulse combustion chamber (Fig. 1). For our applications, the most important feature was the position of combustion chamber outside the turbo unit shaft. The GTD-350 engine does not have classic engine construction that is: compressor, combustor and turbines one after another. Unlike the classic engine, GTD-350 has its air ducts placed after compressor to deliver air to a combustor chamber located at the end of the engine. Exhaust gases are then directed to the high pressure (HPT) and low pressure turbine (LPT) that are located between the compressor and combustor chamber. Exposure of combustor chamber gives the opportunity for fairly easy replacement and potential update of turbine system.

\section{General engine design evaluation}

The compressor is located at the beginning of the engine. The air is delivered to the compressor via the compressor's diffuser. Air is compressed by seven stages of the axial compressor and one stage of the radial one. The air is transferred into the combustor chamber via two horizontal air supply ducts. The combustor chamber is located in the rear part of the engine. The direction of the air stream changes by 180 degrees in the combustor chamber. Next, the air stream flows into the turbines' rotor. The turbines are positioned co-axially. One stage of the high pressure turbine (HPT) propels the compressor. Two stages of the low pressure turbine (LPT) drive the main and tail rotors of the helicopter via engine's main transmissions.

The LPT's hot discharged gases are transferred into the gas collector and then to the exhaust tubes. The exhaust gases are directed to ambient via two exhaust tubes.

\section{GTD-350 thermodynamic (analytical) model}

To make a proper comparison of the constant-pressure vs. constantvolume combustion processes, an analytical model of the GTD-350 engine (constant-pressure combustion process) should be evaluated first [6]. Therefore, thermodynamic analytical model of the GTD-350 was created, based on the available documentation and data. The analytical model of the GTD350 engine takes into account every component across the main path: the 

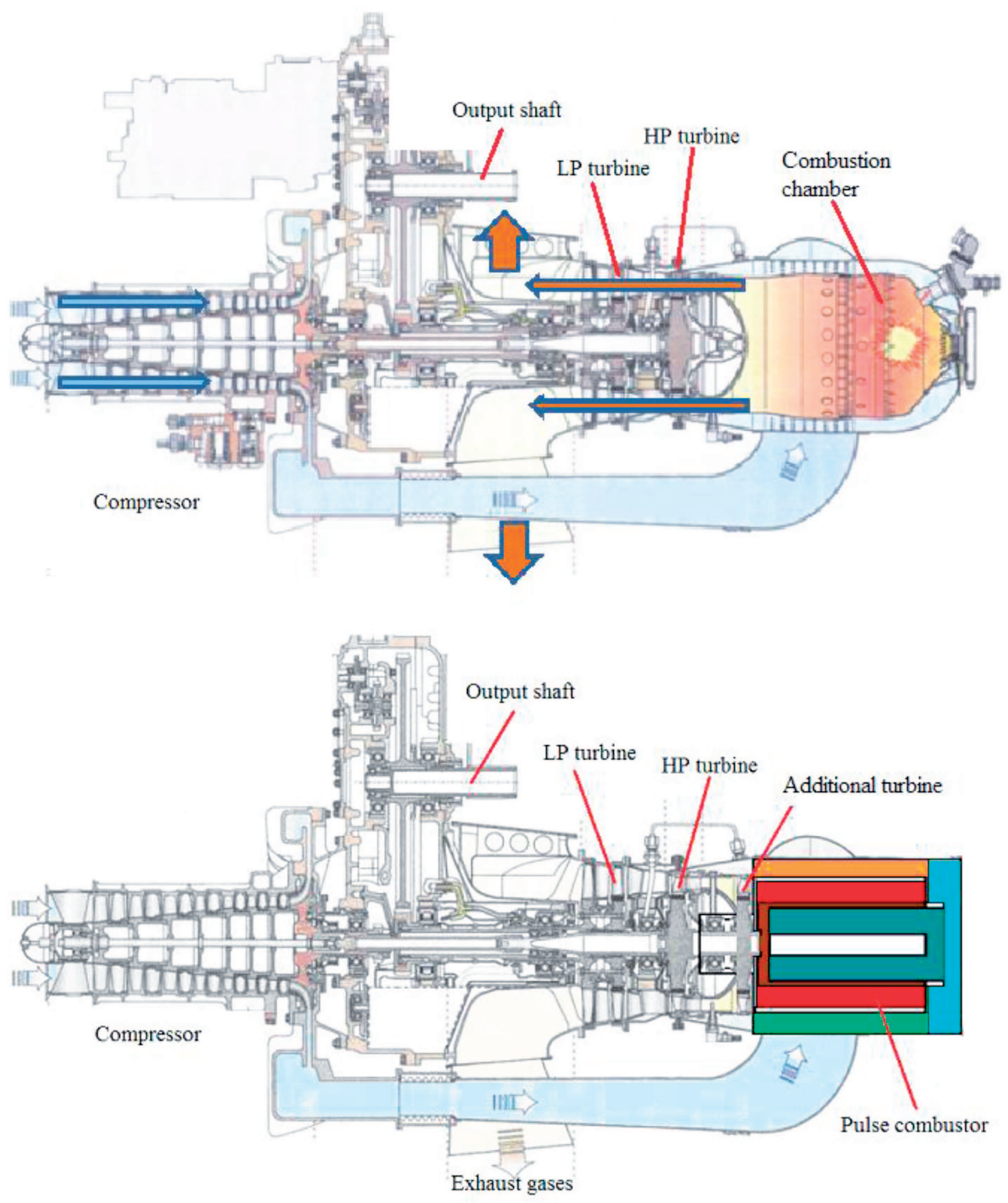

Fig. 1. Scheme of GTD-350 original engine configurations and proposed modifications

diffuser, the compressor, the air ducts, the HPT and the LPT. Not all technical data of the engine were available, so that some assumptions were made. The assumptions were based on professional literature and the available GTD-350 data. The assumptions, as well as the entire thermal analytical model, were further validated. Validation results are described in this paper. The following part of the article concerns description of the GTD-350 components. The intention of the analysis was the comparison of maximal performances of the engines. For this reason, the analytical model was created for maximal power operation conditions. 


\section{Analytical model validation}

An analytical model of the GTD-350 engine was created. It represents the following sections of the GTD-350: the compressor's diffuser, the compressor, the air ducts, the combustor chamber, and the high pressure and low pressure turbines. Documentation of the GTD-350 engine does not provide all the required variables that are needed to describe the GTD-350 engine operation conditions. Thus, the analytical model was based on the available engine parameters. Additionally, the analytical model assumptions were compared with the data from professional engineering documents.

\section{Pulse combustor updates}

The GTD-350 engine, due to his construction, is suitable for evaluating the redesign of the combustor chamber. The original combustor chamber is located at the rear part of the engine. Thus, the combustor can be easily replaced by a constant-volume combustor chamber. Further in this paper, it will be designated as the pulse combustor (PC). Figure 2 shows the components of the rotor pulse combustor.

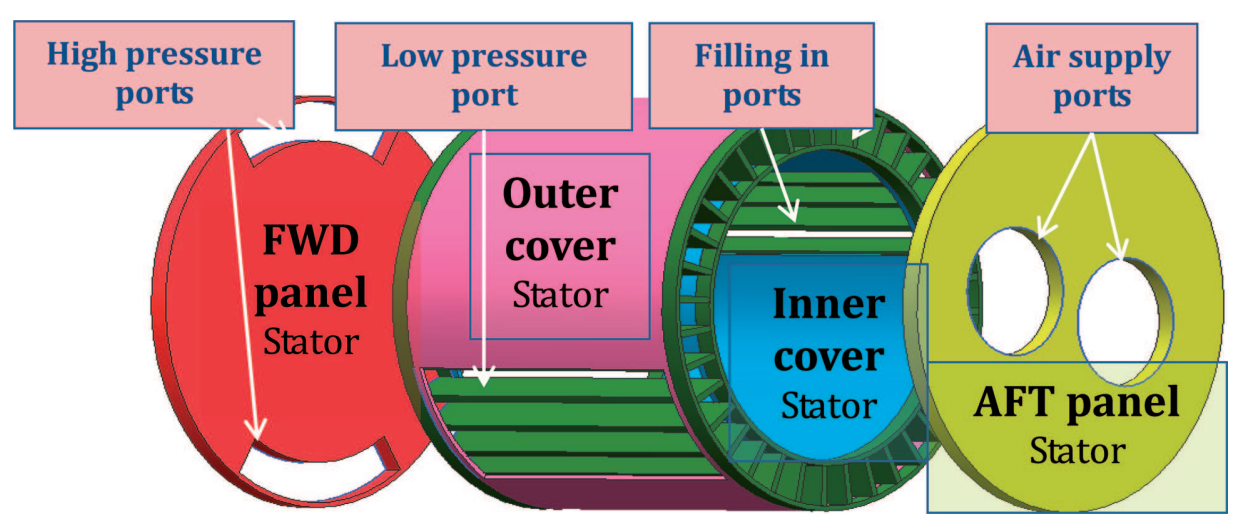

Fig. 2. Pulse combustor components

\section{Pulse combustor operation}

The air ducts are connected to the rear part of the rotor pulse combustor (RPC). Fresh air is delivered into the inner cavity within the RPC. Fresh air is supplied to the rotor's cells by the ports located within the inner rotor cover. Fresh air pushes out the residual exhaust gases from the wave rotor's cells via low pressure ports. The inner cover port is closed when fresh air fully fills in the rotor's cells. The fuel nozzles are fastened to the outer covers of the rotor. 
Fuel is injected into the rotor's cells. The air and fuel mixture is formed as a result. Air and fuel mixture is ignited. The air and fuel mixture burns at constant volume, and exhaust gases are produced as a result. The burning air and fuel mixture increases pressure and temperature within the rotor's cells. Next, the ports in the RPC panel are opened. Sudden port opening causes that decompression wave occurs at the beginning of the wave rotor's cell. Decompression wave travels along the wave rotor's cell towards the aft end of the cell. Then, decompression wave bounces from the aft panel, and travels along the cell towards the RPC panel. The ports in the RPC panel are closed when the decompression wave reaches the panel.

The residual exhaust gases are present in the rotor's cells. The low pressure exhaust gases should be pushed out from the rotor's cells through the low pressure ports. Therefore, the ports in the inner and outer cover of the rotor open and fresh air fills in the rotor cells. This cycle repeats continuously.

\section{Comparison between advantages of constant-volume combustion process and constant-pressure combustion process}

In Fig. 3, thermodynamic cycles including constant pressure and constant volume combustion are presented and compared. The main difference exists between the theoretical maximum temperatures (in the case of constant pressure combustion, the temperature is limited by the turbine inlet temperature). For proper operation, the outlet pressure of pulse combustion chambers should be slightly lower than the pressure before the combustion chamber. This results in lower temperatutre just before the high pressure turbine (HPT).

Taking into account the same added heat, we can calculate and compare the maximal temperatures.

$$
Q=\stackrel{o}{m} \cdot c \cdot \Delta T \Rightarrow \Delta T=\frac{Q}{\frac{o}{m \cdot c}}
$$

Where,

$\mathrm{Q}[W]$ - Added heat (air and fuel mixture combustion)

$\mathrm{cp}=1004.5\left[\frac{\mathrm{J}}{\mathrm{kg} \cdot \mathrm{K}}\right]-$ Specific heat at constant pressure

$\mathrm{cv}=717.5\left[\frac{\mathrm{J}}{\mathrm{kg} \cdot \mathrm{K}}\right]-$ Specific heat at constant volume

$\Delta \mathrm{T}$ - Temperature increase

The constant-volume combustion process, in comparison with the constantpressure combustion one, has a lower specific heat. Thus, the temperature increase of exhaust gases is $\sim 40 \%$ higher for constant-volume combustion than that for constant-pressure combustion for the same amount of heat (fuel) 


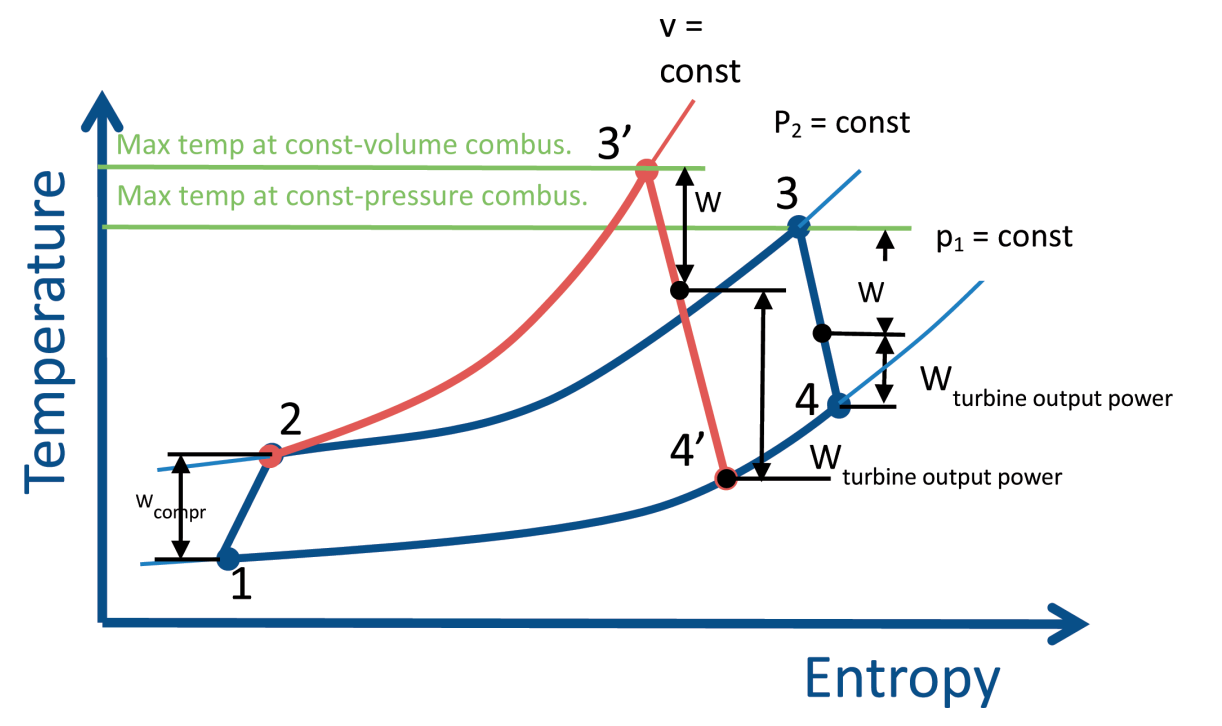

Fig. 3. Constant-volume combustion vs. constant-pressure combustion processes - T-S chart

added during the combustion process. Less fuel is consumed to maintain the same max combustion temperature as well. Additionally, constant-volume combustion process increases the exhaust gases pressure. Higher combustion exhaust gases temperature and pressure have a direct impact on the engine's performance and efficiency. Thus, constant-volume combustion is much more efficient in comparison with the constant-pressure combustion process.

\section{Basic engine updates for pulse combustor application}

The GTD-350's high and two low turbines stages were designed to operate at subsonic flow. Thus, additional pressure increase during constantvolume process causes that pressure drop across turbines exceeds critical value. This means that the turbine will operate at supersonic conditions. This will have a negative impact on the turbine's efficiency and, consequently, on overall engine performance and efficiency. We have proposed to use an auxiliary turbine, in the GTD-350 engine with pulse combustion chamber, to maintain nominal pressure drop across the existing HPT and LPT. Exhaust gases from pulse rotor combustor are directed to the auxiliary turbine. Exhaust gases outflow to the auxiliary turbine causes that pressure in the wave rotor combustor decreases. When the pressure (in the PRC) reaches the level of compressor discharge pressure (combustor chamber pressure for constant-pressure combustion), the high pressure ports close. Then, low pressure ports and filling in ports open, and exhaust gases are pushed out to the HPT. Similarly, exhaust gases from the auxiliary turbine are directed to the 
HPT. Consequently, PC's and AT's exhaust gases flow to HPT and then to LPT.

\section{Steady and unsteady decompression comparison}

Rotor pulse combustor is a constant volume type. Decompression wave appears when the wave rotor discharge port opens [7]. Decompression wave travels across the wave rotor's cell and exhaust gases are discharged into the turbines as a result of an unsteady outflow. Figure 4 shows the velocity during steady and unsteady decompression process.

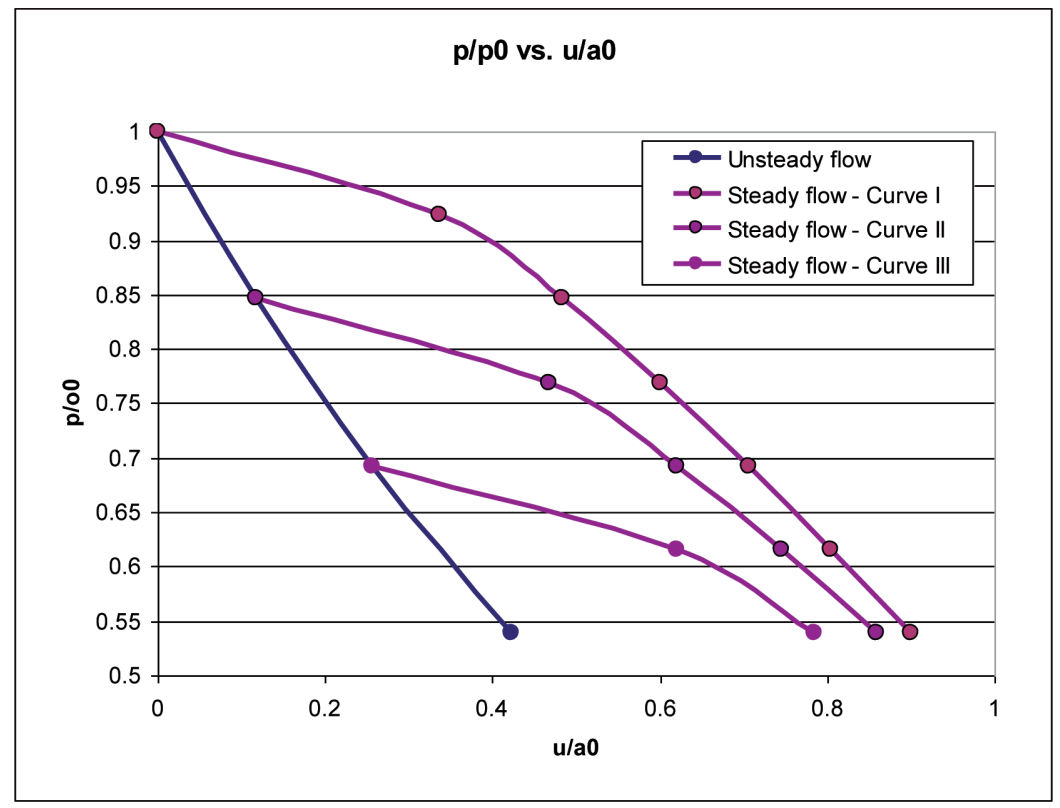

Fig. 4. Steady vs. unsteady expansion flow process comparison

The fluid velocity during unsteady flow is significantly lower than steady flow. This proves that, in the case of unsteady flow, the same pressure drop delivers a lower kinetic energy to the turbine. In result of that, the turbine will generate less power compared to the steady flow case. The nozzle was installed at the end of wave rotor combustor's cell to overcome this inconvenience (Fig. 5). The nozzle's area is smaller than the cell's cross section area. Therefore, the outflow from the wave rotor combustor cell is lower. This causes that exhaust gases are discharged in a quasi-steady manner. For the same pressure drop, quasi-steady flow causes that higher kinetic energy can be gained across turbine. Consequently, quasi-steady flow across turbine is more efficient in comparison to the unsteady one. 


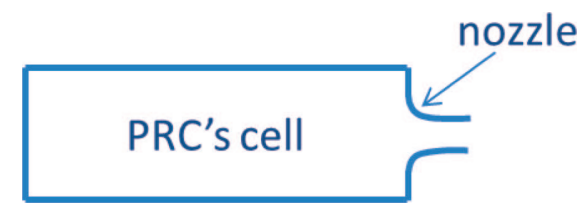

Fig. 5. Wave rotor combustor's cell and nozzle

The analytical model of the GTD-350 engine was updated to reflect wave rotor combustor application. The calculations in the next section of the article illustrate comparison of GTD-350 baseline application vs. pulse rotor combustor application.

\section{GTD-350 vs. GTD-350 \& PC calculation results and conclusions}

Figure 6 shows the layout of the basic engine and the engine with updated constant-volume combustion. The GTD-350 engine's diffuser is located at the front of the compressor to decrease aerodynamics losses. The air is compressed in the compressor and is delivered by the air ducts to the combustion chamber which is located at the end of the engine. The fuel nozzles inject the fuel

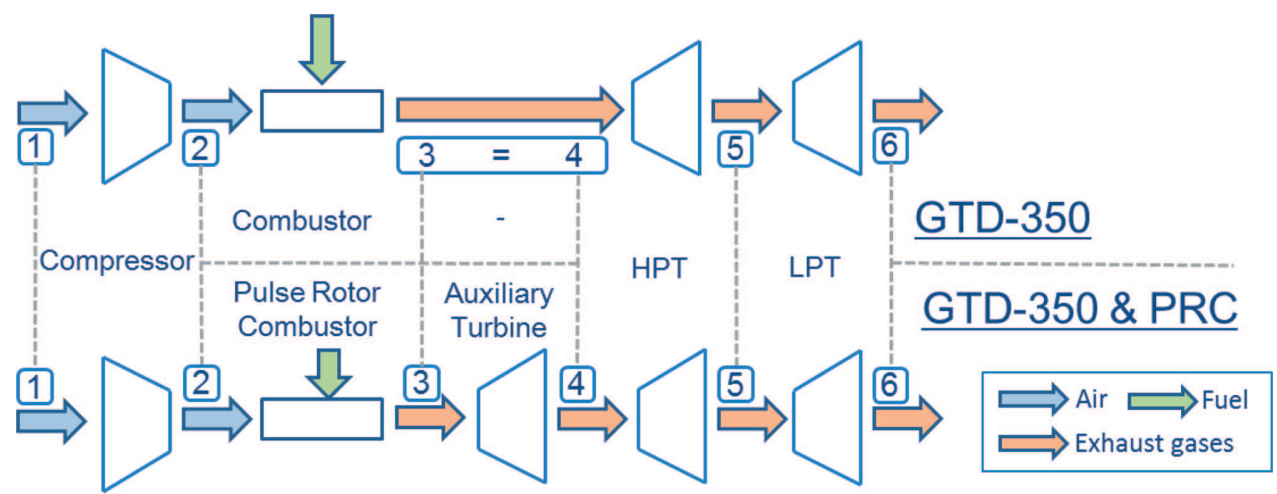

1-2 compression process; 2-3 combustion process; 3-4 Auxiliary turbine (AT) decompression (occurs only for GTD-350 \& PC); 4-5 HPT decompression; 5-6 LPT decompression

Fig. 6. Flow diagram for the basic engine and engine with the pulse combustor

to the combustor chamber and, as a result, air and fuel mixture is formed. Constant-pressure combustion process occurs. Thus, exhaust gases temperature increases without pressure change. Hot exhaust gases flow into the HPT. Pressure and temperature of exhaust gases drop across the turbine. The power produced the in HPT is consumed to propel the compressor. Next, exhaust gases flow into the LPT, which produces the engine output power. The LPT power is delivered to the helicopter's propeller shaft. Two exhaust ducts direct exhaust gases outside. The updated GTD-350 with pulse combustor chamber 
has the same diffusor, compressor, high and low pressure turbines. The only change is that the classic combustor chamber is replaced by the Pulse Rotor Combustor (PRC). In addition, a new Auxiliary Turbine (AT) is added to the existing GTD-350 engine. This configuration will be further named the GTD-350 \& PRC. Compressed air is delivered into the PRC by air ducts. Fuel nozzles inject fuel into the inner cavity of the PRC and, as a result, air and fuel mixture is formed. Filling in ports open, and air and fuel mixture is delivered into the PRC's cells. Filling in ports close, and constant-volume combustion occurs. Temperature and pressure of exhaust gases rise during the combustion of the air and fuel mixture. Outlet ports open, and exhaust gases are discharged into the AT. The exhaust gases, after passing through the AT, are directed to the HPT inlet cavity. The nozzles installed at the PRC's cell outlet cause that the outflow process is relatively slow, and its course is quasi-static. The high pressure ports close when pressure of exhaust gases within the PRC's cells drops to the level of compressor discharge pressure. Then, the low pressure ports and the filling-in ports open. Exhaust gases of the PRC's cells are pushed out by fresh air and fuel mixture. Exhaust gases are delivered to the HPT inlet cavity. The rest of the GTD-350 cycle remains the same as for a conventional GTD-350 revolution.

Figure 7 shows total pressure for GTD-350 vs. GTD-350 \& PRC cycles. The compression processes for GTD-350 and GTD-350 \& PRC engine versions are the same, so that the line segment 1-2 is identical for both versions. The GTD-350 has constant-pressure combustion process. For this reason, the segment 2-3-4 indicates constant pressure of 500.5 kPa. However, GTD-350 $\&$ PRC has constant-volume combustion process. Therefore, with the same amount of fuel burned during the combustion

process in both applications, total pressure in GTD-350 \& PRC application rises up to $1500.5 \mathrm{kPa}$. The segment 3-4 indicates decompression process in the AT, which takes place only in the GTD-350 \& PRC application. As it can be seen, AT generates additional power which is an advantage over the GTD-350 engine baseline. The segment 4-5 indicates HPT decompression process. HPT generates power that is entirely consumed by the compressor. HPT discharge pressure (station $5-177.9 \mathrm{kPa}$ ) for GTD-350 \& PRC is slightly lower than for GTD-350 (stage $5-198.3 \mathrm{kPa}$ ). This is due to the fact that temperature of exhaust gases at the HPT inlet is lower for GTD-350 \& PRC compared to that for GTD-350 engine. This is shown in the Figure 9. In consequence, pressure drop across the GTD-350 \& PRC's HPT must be higher to drive the compressor which consumes the same amount of power for both applications. As a result, LPT inlet pressure is lower, therefore a smaller pressure drop across the HPT and LPT is observed for GTD-350 \& PRC application. The line segment 5-6 indicates the LPT's decompression 


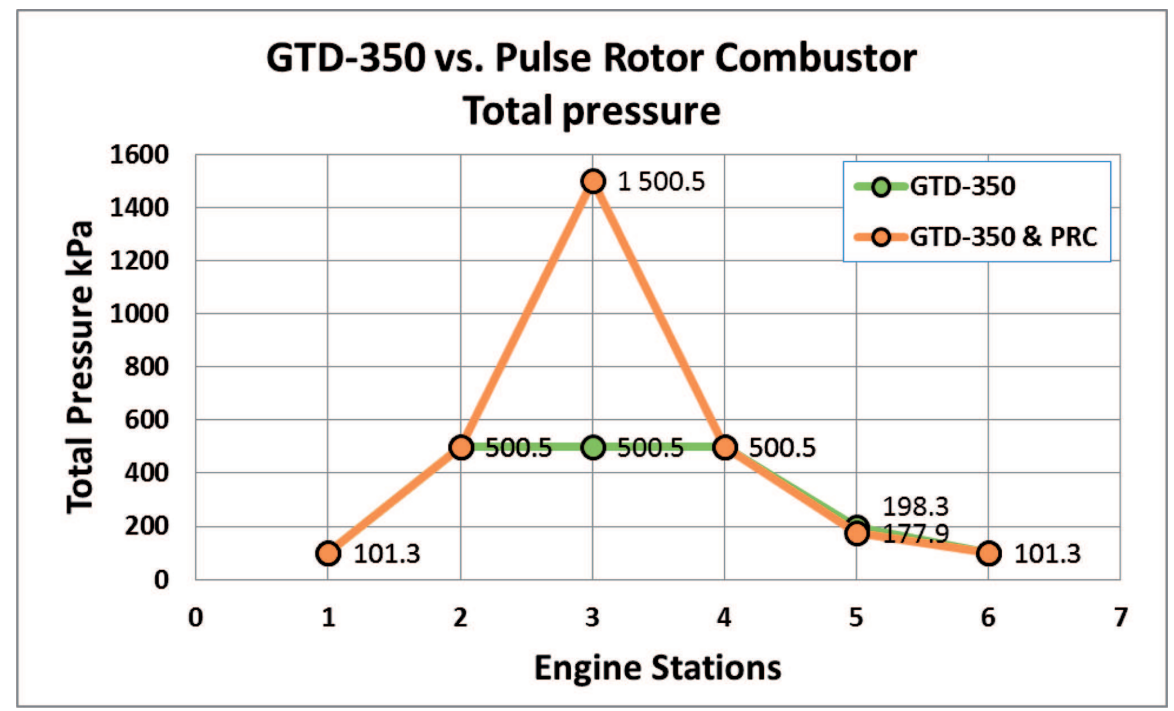

Fig. 7. GTD-350 vs. GTD-350 \& Pulse rotor combustor - Total pressure

process. In both applications, exhaust gases are decompressed to ambient pressures.

Figure 8 shows total temperature cycles for GTD-350 vs. GTD-350 \& PRC. The compression processes in GTD-350 and GTD-350 \& PRC engine versions are the same. Because of this fact, the lines 1-2 are identical. Lines 2-3 indicate combustion process. GTD-350 \& PRC has constant-volume combustion. Therefore, maximal combustion temperature in GTD-350 \& PRC version is higher compared to GTD-350's constant-pressure combustion, which is due to lower constant-volume specific heat. The orange line 3-4 indicates AT decompression. At station 4 (HPT inlet station), GTD-350 \& PRC's temperature drops below GTD-350's temperature. As a result, exhaust gases of lower temperature flow into HPT and then into LPT. Moreover, GTD-350 \& PRC's LPT discharge temperature is lower. This means that the engine discharge loss is lower. Therefore, the GTD-350 \& PRC cycle is more efficient of GTD-350.

In Fig. 9 there is presented the temperature - entropy relation. The constant volume combustion cycle is characterized by a lower entropy increase for delivered heat means higher thermal efficiency.

We created a baseline analytical model for the GTD-350 engine cycle. Next, the analytical model was validated based on the available documentation and data. Then, the analytical model was updated to represent constantvolume combustion process. Instead of a classic combustion chamber, a wave rotor combustor was modeled. Additionally, a new turbine was added to the GTD-350 engine, to take advantage of the PRC. The performed analyses of 


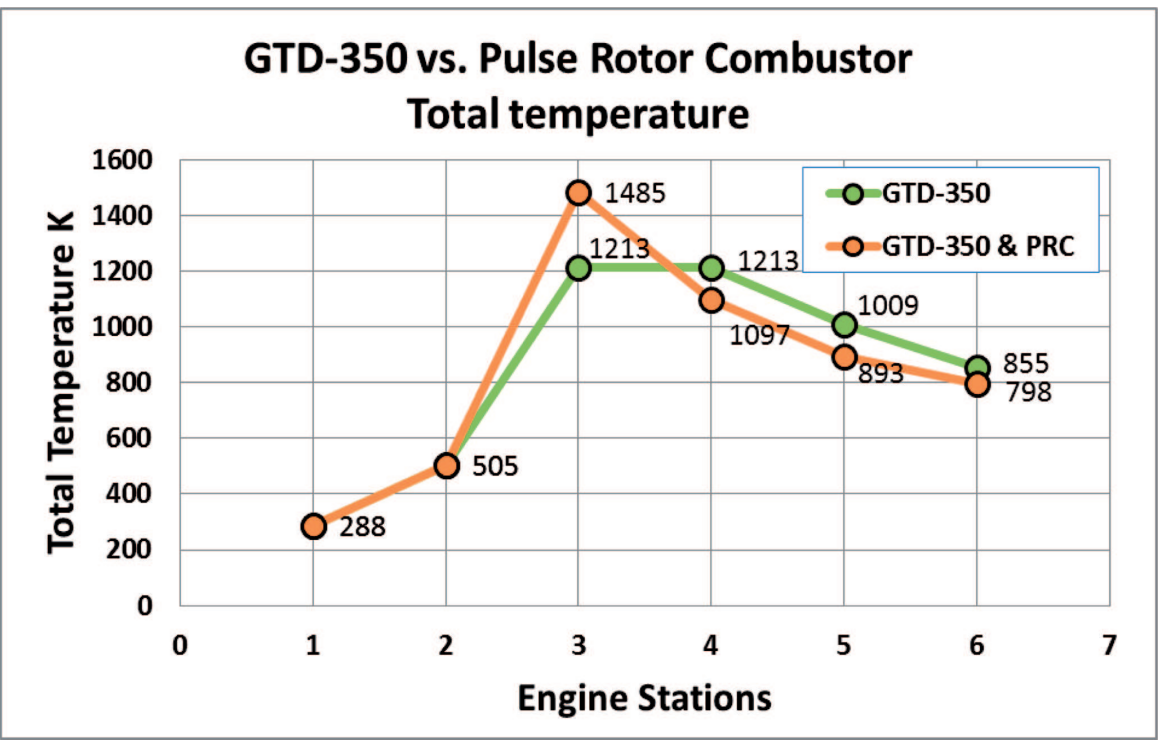

Fig. 8. GTD-350 vs. Pulse rotor combustor - Total temperature

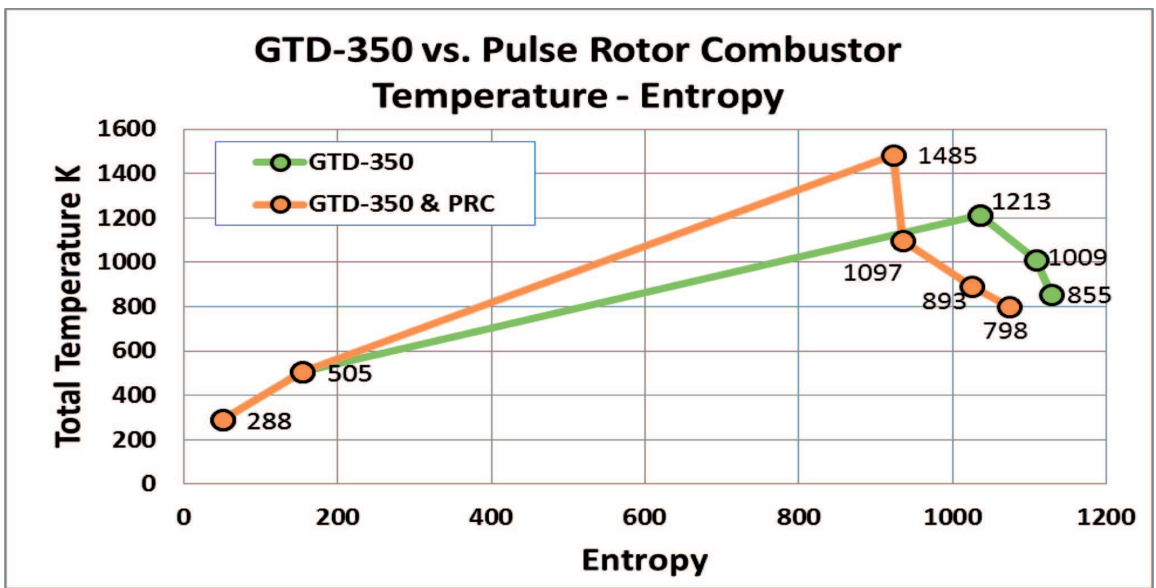

Fig. 9. GTD-350 vs. GTD-350 \& PRC - Temperature - Entropy chart

Table 1.

GTD-350 vs. GTD-350 \& PRC engine performance and efficiency comparison

\begin{tabular}{|c|c|c|c|c|}
\hline \multirow{2}{*}{ Engine Version } & \multicolumn{3}{|c|}{ Power [KW] } & \multirow{2}{*}{ Efficiency } \\
\cline { 2 - 5 } & LPT & AT & Total & \\
\hline GTD-350 & 294.2 & - & 294.2 & 16.97 \\
\hline GTD-350\&PRC & 220.6 & 199.6 & $\mathbf{4 2 0 . 2}$ & 24.24 \\
\hline
\end{tabular}


GTD-350 vs. GTD-350 \& PRC cycle showed that constant-volume combustion is more efficient. The results of analysis are collected in Table 1. Despite the fact that LPT (engine output turbine) for the GTD-350 \& PRC generates less power than the GTD-350 engine, the overall engine performance is higher owing to the AT installed on the engine. The AT generates $\sim 47.5 \%$ of total engine power vs. LPT $\sim 52.5 \%$. Engine performance, as well as its efficiency was improved. This means that the changes in the existing GTD350 engine are profitable. The engine performance was increased by about $42.84 \%$. Similar improvement of $42.84 \%$ was achieved for the overall engine efficiency.

Installation of a new hardware on an existing engine is a challenging task. However, GTD-350 is not a classically-configured engine. This means that the additional turbine on the engine and the PRC instead of the combustion chamber do not affect the functioning of any of the following main engine components: diffuser, compressor, HPT as well as LPT. Therefore, it is feasible and profitable to update the existing GTD-350 engine to get a constant-volume combustion process. The AT can propel an electrical generator. It is possible for the AT turbine to be supported by a separate bearing. Moreover, AT's shaft can be independent. This means that there is no need to install the complicated synchronization system of LPT and AT shafts.

\section{Summary}

The GTD-350 engine was selected for evaluation due to the fact that its construction is different from classic engines, and the combustion occurs as a constant-pressure process. The combustion chamber is located at the rear part of the engine. This gives the opportunity to make relatively easily changes in the combustor chamber hardware and introduce the additional turbine installation. Therefore, the GTD-350 engine was used as a benchmark. A thermal analytical model of the GTD-350 engine was created and validated based on the available documentation and data. The analytical model calculations included all the GTD-350 components. Thus, the entire engine cycle was modeled. The parameters of engine's main path were calculated, and used as a benchmark. The constant-volume combustion process was described. All the changes needed to introduce the constant-volume combustion process into the GTD-350 engine were described as well. Thermal analytical model was updated to reflect changes made within the engine. Performance and efficiency were compared to the GTD-350 and the GTD-350 \& PC engine applications, based on the analytical models. The results prove that constantvolume combustion is beneficial compared to the constant-pressure combustion processes. This is due to the fact that during constant-volume combustion 
process not only temperature, but also pressure is increased. Moreover, specific heat of constant-volume combustion is lower than for constant-pressure combustion processes. For this reason, maximal combustion temperature is higher, or less fuel is needed to increase the temperature to the same level as for the constant-pressure combustion process. To take advantage of the PRC application, an AT was installed on the engine. Owing to the engine configuration, installation of the PRC and AT did not require any changes in main engine components. The AT can additionally propel an electrical generator. Therefore, there is no need to use the complicated and expensive turbine synchronization system.

The calculations of engine efficiency and performance done for the existing GTD-350 engine showed that constant-volume combustion process is valuable. Majority of engines use constant-pressure combustion processes, which are less efficient than constant-volume combustion processes. The GTD-350 engine was selected due to the fact that changes in the combustion chamber hardware could be easily implemented. However, if the devices allowing constant-volume combustion were implemented during the engine design process, every engine could be easily designed to take advantage of constant-volume combustion process. For this reason, the next generation of engines might be more efficient, constant-volume combustion engines.

Manuscript received by Editorial Board, May 25, 2012;

final version, May 06, 2013.

\section{REFERENCES}

[1] Kurec K., Piechna J., and Müller N.: Numerical investigation of the radial disk internal combustion engine, POWERMEMS 2009, 0175.

[2] Snyder P.H., Alparslan B., Nalim R.M.: 2002, Gas dynamics of the CVC, a novel detonation cycle, AIAA 2002-4069.

[3] Piechna J.: "Numerical Analysis of Micro Ring-Engine Fluid Dynamics", The Archive of Mechanical Engineering, 2009, Vol. LVI, Nr 2, pp. 173-189.

[4] Piechna J., Dyntar D.: Hybrid wave engine concept and numerical simulation of engine operation, The Archive of Mechanical Engineering, Vol. LVII 2010, Number 1, 2010, 69-93.

[5] Wytwórnia sprzętu komunikacyjnego „PZL Rzeszów”, Opis techniczny silnika GTD-350 dla śmigłowca Mi-2, Rzeszów 1978, 1-11.

[6] Cohen H., Rogers G.F.C., Saravanamuttoo H.I.H.: Gas Turbine Theory, Longman 1996.

[7] Shapiro A.H.: The Dynamics and Thermodynamics of Compressible Fluid Flow, John Wiley and Sons, 1958. 
Ulepszenie silnika turbinowego przez zastąpienie konwencjonalnej komory spalania przez pulsacyjną komorę spalania

\section{Streszczenie}

W pracy przedstawiono opis silnika turbinowego i jego termodynamicznych modeli analitycznych. Model analityczny został stworzony w celu oceny wpływu pulsacyjnej komory spalania o spalaniu przy stałej objętości na parametry pracy silnika. Przedstawiono i omówiono koncepcję wirnika falowego z pulsacyjnymi komorami spalania. Opisano zalety spalania w stałej objętości, a także omówiono wymagane zmiany w konstrukcji silników turbinowych, konieczne przy wykorzystaniu spalania przy stałej objętości. Porównano modele termodynamiczne silnika w wersji podstawowej i wyposażonej w pulsacyjną komorę spalania. Artykuł opisuje niezbędne zmiany w strukturze silnika oraz jego budowie i szacuje zmiany jego podstawowych parametrów. Osiowy typ wielokomorowego urządzenia które w sposób pulsacyjny zwiększa ciśnienie i temperaturę gazów wymaga specjalnej dodatkowej turbiny. Wykorzystanie dodatkowej energii wymaga ukształtowania współpracy pulsacyjnej komory spalania ze standardowym układem sprężarka-turbina. Obliczenia przeprowadzone dla istniejącego silnika GTD-350 wykazały, że zastosowanie procesu spalania w stałej objętości podnosi moc i sprawność silnika. 